\title{
The progression of osteopathic medicine internationally: A survey of America-trained DOs practicing abroad
}

\author{
G. JUDE SHADDAY, DO \\ GREGORY G. PAPADEAS, DO \\ LORI L. SMITH, DO
}

\section{While DOs in the United}

States are fully licensed in every parameter of health care, with unlimited privileges in medicine and surgery in every state, many US-trained DOs now practicing abroad do not necessarily enjoy the same medical privileges as their American colleagues. The authors report their survey findings concerning types of practices, licensure, and the use of osteopathic practices and principles in 19 foreign countries.

Osteopathic medicine has emerged as an American reformation in health care, and in the United States, osteopathic physicians and surgeons are fully licensed in every state in all areas of health care. Worldwide, however, osteopathic physicians do not necessarily enjoy the same medical privileges as their American colleagues. Because some US-educated Doctors of Osteopathy (DOs) are expanding their practices internationally, we undertook a survey to investigate the practices of DOs in foreign countries.

\section{Report of study \\ Methodology}

Sixty-one US-trained DOs in 24 countries throughout Europe and the Middle East, the West Indies and Central and South America, Australia and the South Pacific, Asia, and Africa were surveyed. Because of its proximity, Canada was not surveyed. However, two DOs who had part of their postgraduate training in Canadian hospitals were interviewed.

A questionnaire was sent to DOs who were listed

in the 1984-1985 and 1985-1986 AOA directories ${ }^{1,2}$ as living in foreign countries. The 33 questions elicited information concerning licensure, types of practice, status relating to the use of osteopathic principles, and general acceptance of DOs abroad. The answers ranged from yes/no responses to brief explanations. Many physicians included pertinent comments regarding their individual practices. Some DOs who previously had practiced abroad but had returned to the United States were interviewed personally.

\section{Results}

Table 1 presents the compiled data from the survey. Of the 61 DOs surveyed, $25(41 \%)$ responded. Seventy-five percent of the surveyed countries are represented in the results. The regulations of each country are presented individually. It is possible that some DOs practicing abroad were not surveyed, especially those in the military services and those not affiliated with the AOA.

Europe and Middle East. In England, DOs are restricted to the practice of osteopathic manipulative therapy (OMT). (The contrast between the training of practitioners in England and those in the United States is detailed later in this article.) No licensure is required for this type of practice. The status is best described by a British DO trained in the United States: 'Under the Common Law, anyone can practice OMT with or without recognized qualification. But the atmosphere is changing since the Prince of Wales gave his nod to complementary medicine (including acupuncture, herbalism, homeopathy, etc), and the Royal Colleges have set up a commission to investigate the claims of each 
movement.' There is an attempt toward understanding osteopathic medicine as practiced in England and defining its role in the British medical system.

In West Germany, a few DOs are practicing under US military jurisdiction, on US army bases. However, one respondent states that licensure might be obtained through the West German government.

One DO completed his plastic surgery residency in Sweden. He was considered to be an employee of the Swedish government because of its socialized medical system. He had full privileges to practice medicine and surgery. This opportunity was arranged after he had spent part of one of his undergraduate rotations doing research in Sweden. Through his residency program, he also was able to do some training in France.

Norway has a similar status to that found in England and Australia, with practice being limited to OMT.

Sweden, Greece, and Iran were surveyed, but didn't respond.

In Israel, US-trained osteopathic physicians are privileged to practice both medicine and surgery after gaining a permanent license. For the first two years, under a temporary and renewable license, they are granted privileges that exclude surgery. During the third year, they can apply for a permanent license, which includes an unlimited practice. Interestingly, they are unable to use the initials DO for their title, because all medical doctors have the title physician on their license.

West Indies, Central America, and South America. The respondent from Haiti practices as a "general practitioner" through a missionary clinic. Licensure was obtained from the Haitian government as part of the clinic's operations. There is no limit on medical or surgical privileges.

A respondent from Honduras states that his legal rights are held by a permit issued by the Department of Health of the Honduran government. $\mathrm{He}$ is restricted medically as a physician; however, he serves as a public health official doing missionary work. He notes that licensure for any foreign physician is very difficult to obtain.

Unlimited practice privileges were finally obtained by one DO in Peru. The process included the completion of clinical rotations at a Peruvian medical college as well as taking oral, written, and practical examinations in medicine, surgery, obstetrics, gynecology, and pediatrics in the Spanish language. This enabled enrollment into the $\mathrm{Na}$ tional Health Ministry.
Bermuda and Mexico were surveyed, but did not respond.

Australia and South Pacific. Australia's situation is similar to England's, in that DOs likewise are restricted to OMT. However, they must be registered under the "Osteopathic and Chiropractic Act-1978." Unfortunately, immigration officials are making Australian visas very difficult to obtain for osteopathic physicians.

In Papua New Guinea, there presently is an independent government, which has no procedures to license DOs. The DOs there were licensed under the previous colonial government to practice all aspects of medicine and surgery.

Asia. Information was obtained from the Philippines, Taiwan, Hong Kong, Thailand, Indonesia, and India.

In the Philippines, DOs enjoy practicing all aspects of medicine and surgery. There currently is a DO practicing in a church hospital in Taiwan. The purpose for entering Taiwan was to help maintain the pediatrics department at the hospital while two Chinese pediatricians were in the United States for further training. He has unlimited privileges as a pediatrician. The respondent stated that the possibility of practicing there was enhanced after extensive documentation of the status of osteopathic medicine in the United States and by his being certified by the allopathic American Academy of Pediatrics.

In Thailand, two DOs were pursuing licensure together, a husband-wife team (one responded for both). Presently, they are limited to public health. They anticipated the ability to practice all aspects of medicine and surgery. They initiated a visit of a member from the Thai Medical Society to the Philadelphia College of Osteopathic Medicine, the Oklahoma College of Osteopathic Medicine and Surgery, and the national office of the American Osteopathic Association. These meetings were arranged specifically to present the facilities and the nature of the education of an osteopathic physician. Even with such exposure, the Thai government finally rejected their application for full privileges.

In Indonesia, although DOs may practice unlimited medicine and surgery, they can gain entrance only if they are going to do missionary work. The waiting period for obtaining a visa is approximately two years.

Responses from India indicate that licensure has not yet been obtained. However, one DO is awaiting approval. Both respondents practice all aspects of obstetrics and gynecology with the approval of 
TABLE 1. SURVEY DATA FROM OSTEOPATHIC PHYSICIANS AND SURGEONS PRACTICING ABROAD.

\begin{tabular}{|c|c|c|c|c|c|c|c|c|}
\hline $\begin{array}{l}\text { Country } \\
\text { surveyed }\end{array}$ & $\begin{array}{l}\text { No. of } \\
\text { respondents/ } \\
\text { no.surveyed }\end{array}$ & $\begin{array}{c}\text { Area of } \\
\text { specialization }\end{array}$ & $\begin{array}{c}\text { Associated } \\
\text { with an } \\
\text { organization? }\end{array}$ & $\begin{array}{l}\text { Licensed } \\
\text { through } \\
\text { host } \\
\text { government }\end{array}$ & $\begin{array}{l}\text { Legal } \\
\text { restrictions }\end{array}$ & $\begin{array}{l}\text { Do you } \\
\text { practice } \\
\text { OMT? }\end{array}$ & $\begin{array}{c}\text { Member } \\
\text { of } \\
\text { AOA? }\end{array}$ & $\begin{array}{l}\text { Interested } \\
\text { in US } \\
\text { students } \\
\text { for rotation? }\end{array}$ \\
\hline Australia & $3 / 8$ & OMT & Private practice & Yes & Yes & Yes & Yes & Yes \\
\hline Canada* & $2 / 2$ & $\begin{array}{c}\text { Hospice Society (F) } \\
\text { Neurology (R) }\end{array}$ & McGill University & $\mathrm{No}^{8}$ & $\mathrm{No}^{\S}$ & $?$ & Yes & No \\
\hline England & $4 / 20$ & OMT & $\begin{array}{l}\text { British Osteopathic } \\
\text { Association }\end{array}$ & No & Yes & Yes & Yes & Yes \\
\hline Haiti & $1 / 1$ & General practice & Mission & Yes & No & Yes & Yes & Yes \\
\hline Honduras & $1 / 1$ & $\begin{array}{l}\text { General practice/ } \\
\text { public health }\end{array}$ & Mission & No & Yes & Yes & Yes & No \\
\hline Hong Kong & $1 / 1$ & Retired & No & No & $?$ & $?$ & $?$ & $?$ \\
\hline India & $2 / 3$ & $\begin{array}{l}\text { Obstetrics/ } \\
\text { gynecology }\end{array}$ & Mission & Not & No & Yes & Yes & Yes \\
\hline Indonesia & $1 / 1$ & $\begin{array}{c}\text { General practice/ } \\
\text { surgery }\end{array}$ & Mission & Yes & No & Yes & Yes & No \\
\hline Israel & $2 / 3$ & $\begin{array}{l}\text { Obstetrics/ } \\
\text { gynecology } \\
\text { Pediatrics }\end{array}$ & Private practice & Yes & No & Yes & Yes & Yes \\
\hline Kenya & $1 / 1$ & $\begin{array}{c}\text { Pediatrics/ } \\
\text { teaching research }\end{array}$ & $\begin{array}{l}\text { University of } \\
\text { Nairobi }\end{array}$ & Yes & No & Yes & Yes & Yes \\
\hline Liberia & $1 / 2$ & Student rotation & Mission & No & No & $?$ & $?$ & No \\
\hline Norway & $1 / 1$ & OMT & Private practice & No & Yes & Yes & Yes & No \\
\hline $\begin{array}{l}\text { Papua } \\
\text { New Guine }\end{array}$ & $1 / 2$ & General practice & Mission & Yes & No & Yes & Yes & Yes \\
\hline Peru & $1 / 1$ & $\begin{array}{l}\text { General practice/ } \\
\text { pediatrics }\end{array}$ & Mission & Yes & No & No & Yes & No \\
\hline Philippines & $1 / 1$ & $\begin{array}{c}\text { General practice, } \\
\text { obstetrics/ } \\
\text { gynecology }\end{array}$ & Private practice & Yes & No & Yes & No & Yes \\
\hline Sweden & $1 / 3$ & Plastic surgery & University & Yes & No & Yes & Yes & No \\
\hline Taiwan & $1 / 1$ & Pediatrics & Mission & Yes & No & Yes & $?$ & Yes \\
\hline Thailand & $1 / 2$ & $\begin{array}{l}\text { Preventive and } \\
\text { tropical medicine } \\
\text { PHO }\end{array}$ & Mission & No & Yes & No & Yes & Yes \\
\hline $\begin{array}{l}\text { West } \\
\text { Germany }\end{array}$ & $1 / 1$ & $\begin{array}{c}\text { Emergency } \\
\text { medicine/ } \\
\text { general practice }\end{array}$ & Armed forces & No & No & Yes & Yes & No \\
\hline $\begin{array}{l}\text { * Personal inter } \\
\text { † Left Kenya pr } \\
\text { † License pendi } \\
\$ \text { The interview } \\
\text { licensed throu } \\
\text { PHO = public }\end{array}$ & $\begin{array}{l}\text { prior to publicat } \\
\text { ding. } \\
\text { wees were there } \\
\text { ough the host gc } \\
\text { lic health officia }\end{array}$ & $\mathrm{F}=$ fellowship, $\mathrm{R}=$ & $\begin{array}{l}t \text { indicate whether the } \\
=\text { residency. }\end{array}$ & $\begin{array}{l}\text { indicate that } \\
\text { are restrictec }\end{array}$ & $\begin{array}{l}\text { teopathic physic } \\
\text { n their practice. }\end{array}$ & cians prati & g in Cans & da are not \\
\hline
\end{tabular}

the Indian government. At one time, the Red Cross financed a US-educated British DO (who has since returned to England), as well as some of his medical colleagues, to establish a maternity center and traveling dispensary in India.

Africa. In Kenya, osteopathic physicians can be licensed in the unlimited practice of medicine and surgery. To gain licensure, a DO must present medical school transcripts and pass oral and written examinations.
As a student, one DO spent part of his scheduled rotation in Liberia. This was done with the approval of the Liberian government. During these rotations, he took care of many of the patients himself because of the lack of physicians in that country.

Canada. According to the America Osteopathic Association, practice for DOs in Canada is dictated by the individual provinces. At the present time, Alberta and Quebec are granting licenses to DOs. 


\section{Discussion}

Acceptance in most British Commonwealth countries is quite different from the United States. The British schools of osteopathic medicine emphasize the training of their students in the art of OMT. The awarded degree is a Diploma of Osteopathy, in contrast to the Doctor of Osteopathy degree awarded in the United States. The DO degree in England and Australia limits its practitioners to the practice of OMT, whereas the title of DO in the United States grants licensure as complete physicians. This leads to complications in the status of US-trained DOs who wish to extend their practices beyond manipulative therapy in those countries.

Are the osteopathic practices and principles (OPP) that were learned during these DOs' medical training being used abroad? According to the majority of responses, the philosophy of osteopathic medicine and the practice of OMT are being used effectively. OPP is being used anywhere that these DOs are practicing, regardless of the type of practice (missionary work, the armed forces, or private practice). Most respondents were emphatic about the value of OPP in providing complete health care. In many cases, allopathic physicians are inquiring about the practice of OMT, and many European physicians are attending seminars in England to learn the art of OMT.

The potential for osteopathic medical students to take part of their training abroad is evident. In fact, several of the respondents enthusiastically encourage students to spend time with them in their host countries (Table 1). There are other avenues through which students interested in spending time abroad can obtain information about specific options. Those affiliated with a specific religion can contact their church or synagogue. Administrators within osteopathic institutions might also be a source of information. Personal contacts with other universities, especially those that are affiliated with medical schools, may offer other opportunities. One might also write directly to organizations or persons in the country of interest.
For licensed DOs who wish further information regarding practicing abroad, resources include the American Osteopathic Association, D.O. Care International, the World Health Organization, the International Red Cross, C.A.R.E., UNICEF, the Peace Corps, and the US State Department. Other opportunities lie in postgraduate or continuing education.

\section{Conclusions}

The reasons for practicing in foreign countries are varied. According to the survey, aside from being in private practice, the greatest number of these DOs are doing missionary work. In addition, there are DOs practicing abroad in the US armed forces. Other graduates of American osteopathic medical schools have gone abroad for residencies, fellowships, and research and teaching positions.

Gaining the appropriate licensure to practice medicine and surgery has been the greatest barrier for DOs in foreign countries. Overall, osteopathic physicians have gained acceptance based on their ability. As several respondents emphasized, their performance as physicians have dictated the reactions of their colleagues and patients. Personal interaction with the medical community has provided the basis for understanding and subsequent acceptance of the osteopathic profession abroad.

The value of osteopathic practices and principles warrants their expansion into health care systems worldwide. Osteopathic philosophy should be shared beyond the United States of America.

1. American Osteopathic Association 1985-1986 Yearbook and Direc tory of Osteopathic Physicians and Surgeons. Chicago, AOA, 1985. 2. American Osteopathic Association. 1986-1987 Yearbook and Directory of Osteopathic Physicians and Surgeons. Chicago, AOA, 1986.

All of the authors were students at the Philadelphia College of Osteopathic Medicine, Philadelphia, when the paper was written.

Reprint requests to Dr Shadday, PCOM, 4150 City Ave, Philadelphia 19131. 